\title{
Baltic States Stock Market Listed Companies' Absolute Value Indicators Analysis
}

\author{
Aija Pilvere-Javorska ${ }^{1 *}$, Irina Pilvere $^{2}$, Baiba Rivza ${ }^{3}$, Peteris Rivza ${ }^{4}$ \\ ${ }^{1,2,3,4}$ Latvia University of Life Sciences and Technologies, Latvia.
}

\begin{abstract}
Financial capital in companies is diverse: it can be own resources, bank funding, state support, as well as funds of investor (risk capital, securities, private investments). Stock market is a subsystem of financial capital market and is a necessary element for development of companies and, thus economy. In Baltic States capital market is relatively new and small. Bank loans dominate in attracting financing in the Baltic States, and there has been limited research on overall the Baltic States stock market listed companies' profile and financial standing. Therefore, it is necessary to analyze the stock market in the Baltic States as a whole. Therefore, the aim of the present research is to perform Baltic States stock market listed companies' absolute value indicators thorough analysis using factor un cluster analysis. The research results showed that Baltic States stock market 50 listed companies' 20 absolute value indicators comprehensive factor analysis aloud to conclude that this market is relatively homogeneous, but has a small number of very large companies with significantly different performance indicators, this was confirmed by cluster analysis outcome, allowing to define average Baltic States stock market listed company profile. The results of this analysis could be used for policy making to stimulate Baltic States stock market development in the future.
\end{abstract}

Keywords: stock market, listed companies, financial analysis, factor and cluster analysis. 


\section{Introduction}

Financial system is an important and significant component of economy. Stock market comovement is an important topic in finance, primarily due to its relevance for asset allocation, portfolio diversification, risk management and functioning of financial systems (Jach, 2017). Capital is an integral part of financial system and is needed for development of companies and, thus economy. The World Economic Forum (2019) notes that "financial and monetary systems represent the cornerstone of economic activity". Financial capital in companies is diverse: it can be own resources, bank funding, state support (subsidies or grants), as well as funds of investor (risk capital, securities, private investments). External financial capital has two main sources: banks and other financial intermediaries providing capital and stock market. Stock market is already a subsystem or subsegment of financial capital market and is comprised of listed companies. S.Nyasha \& N.M.Odhiambo (2014) stated that most of the literature reviewed ... supports bidirectional causality between bankbased financial development and economic growth or reinforces the conventional supplyleading response phenomenon. O.Bustos \& A.Pomares-Quimbaya (2020) stress that "... achieving accurate stock market models can provide investors with tools for making better data-based decisions. These models can help traders to reduce investment risk and select the most profitable stocks". Broad analyses of stock market development has been carried out in Asian countries (Johnson \& Soenen, 2002; Zhang et al., 2017; Liu et al., 2018; Xiaoye, 2018; Chen et al., 2020; Yin et al, 2020 etc.). The European approach to corporate financing raises two questions related to value creation. The first is whether debt financing is associated with higher market valuation. How does a dominant share of debt in the capital structure influence the stock market valuation of a company? The second issue concerns the impact of type of debt on market valuation (Fungáčová et al., 2020). A. Marshall et al. (2019) research results shows that "firms should rely more on loans than bonds as debt financing instruments. The relatively better stock market reaction to loan issuance than bond issuance argues for expanding the syndicated loan market in European countries“. J.Pera (2019) concludes ,that the stock exchanges of Central and Eastern European (CEE) countries are constantly improving their investment position with regard to operational effectiveness and risk mitigation when compared to the largest stock exchanges analysed, ambitiously striving to become significant financial centres within Europe and worldwide". But M.Nitoi \& M.M.Pochea (2016) notes, that ,the existence of a highly fragmented financial market with high structural and institutional differences suggests the need for measures that will increase the financial convergence among CEE countries. ... and policymakers should adopt measures that will increase financial transparency, improve corporate governance and strengthen the regulatory framework“. MA.Thomas \& L.Spataro (2018) conclude that „households' stock market participation has significant effects on savings and on an economy's financial development and performance“. O.Zakharkin et al. (2017) stress that ,the research confirms the decrease of volatility of the stock market when increasing the investment horizon. However, this is more typical of stable European markets".

The banking sector and the stock market in Europe have been adversely impacted by a series of global financial crises over the last two decades... Measures were also implemented to create a vibrant stock market in Europe to stimulate economic growth in Europe (Pradhan et al., 2019). In June 2010, the European Financial Stability Facility (EFSF) was established. It 
was a temporary crisis resolution mechanism that helped to solve some of the acute problems of Ireland, Portugal and Greece. In September 2012, EFSF was replaced by the European Stability Mechanism (ESM). Although ESM is a permanent mechanism that should help Eurozone to cope with the debt crisis (Chovancova \& Hudcovsky, 2016). The global crisis caused by the 2020 pandemic means that "the margins for monetary and fiscal stimuli are also narrower than before the 2008-2009 financial crisis, creating uncertainty about how well countercyclical policies will work. Without economic and social stability, countries could lack the financial resources, fiscal margin, political capital or social support needed to confront key global risks" (World Economic Forum, 2020).

The world experience of investment activity shows that economic growth is impossible without an effective national stock market, which contributes to development of the shared economy and to creation of a community of owners (Podgorny, 2017). In Latvia the capital market is relatively new, as only in 1994 the Cabinet of Ministers approved the concept of stock market development, in 1995 the law "On Sock Market" was adopted and the Riga Stock Exchange and the Latvian Central Depository were established. In 2018, it can be concluded that the stock market has not reached the expected levels, because the capitalization of the Latvian stock market (919 mill. EUR worth of shares of Latvian companies listed on NASDAQ Riga against the gross domestic product and turnover is one of the lowest in Europe ... (Kaužèns, 2018). Authors have noted that there are several factors that determine that companies in Latvia do not want their shares to be listed on the stock market: 1) bank loans dominate in providing financing; 2) additional expenses related to securities; 3 ) lack of analysis of the Latvian stock market. According to the authors, this is also facilitated by the small number of potential investors and the amount of possible financing. Therefore, it is necessary to analyze the stock market not only in one small country, but in the Baltic States as a whole (Estonia, Latvia and Lithuania), because investors see a larger market as more attractive. The Baltic States stock market has not been extensively analyzed, but there are researchers in each country who have analyzed various stock market perspectives. Internationally, the stock market information of some Baltic States is also included in research, for example G.Bóta\& M.Ormos (2015), M.Nitoia \& M.M.Pochea (2016), B.Chovancova \& J.Hudcovsky (2016), however, it does not provide a comprehensive insight into the development trends of this market.

Therefore, the aim of the present research is to perform Baltic States stock market listed companies' absolute value indicators comprehensive analysis using factor un cluster analysis.

Methods. In this research are presented and analysed data of listed companies in three Northern EU countries, which are listed in the Baltics, on Stock Exchanges of Tallinn, Riga and Vilnius. Selected were all the listed companies, and then excluded were financial companies due to their leverage being influenced by different factors compared to nonfinancial companies. Due to the lack of financial data First North Baltic Share List listed companies were also excluded. Another significant research limitation is survivorship biases: since data for the listed companies were taken as of July 24, 2019, thus it excludes all previously delisted companies from those Stock Exchanges during reviewed period, which is from 2004 to 2019, as well as it includes only limited data of other listed companies as of the moment of listing, if they were listed later during review period. Overall maximum number of listed companies at any particular reviewed time with data were 54 in the Baltics States. 
Next step evaluated obtained indicators and variables results, and eliminated were companies were indicators and variables values resulted as 0 or were missing. Thus, recognized as usable and correct for factor un cluster analysis were 50 Baltic States stock market listed companies.

20 absolute value indicators are calculated to be able to classify and determine whether there are commonalities and similarities across listed companies' financial profile. The indicators were calculated in the mill.EUR and they are: 1) Market capitalization - market value of companies shares; 2) Current assets is a company's cash and its other assets that are expected to be converted to cash within one year of the date appearing in the heading of the company's balance sheet; 3) Cash on the balance sheet items is company's cash balance at the end of the reporting period; 4) Total assets are the assets owned by the company that has economic value whose benefits can be derived in the future. Assets are recorded in the balance sheet of the company; 5) Total equity - the value left in the company after subtracting total liabilities from total assets. The formula to calculate total equity is: Equity = Assets - Liabilities; 6) Non-current liabilities include company's long term liabilities, for instance: debentures, long-term loans, bonds payable, long-term lease obligations, and pension benefit obligations; 7) Long-term borrowing represent money borrowed from banks or other lenders to fund the ongoing operations of a business and that will not come due within one year; 8) Current liabilities - amounts due to be paid to creditors within twelve months; 9) Short term borrowing - liabilities that represent money borrowed from banks or other institutions to fund the ongoing operations of a business that will be repaid within one year; 10) Net debt is a liquidity metric used to determine how well a company can pay all of its debts if they were due immediately. Net debt is calculated by subtracting a company's total cash and cash equivalents from its total short-term and long-term debt; 11) Sales revenues are the income that a business has obtained from its normal business activities in the reporting period, usually from the sale of goods and providing services to customers; 12) Annual EBITDA - for any measurement year means consolidated net income before interest, taxes, depreciation, amortization, extraordinary items; 13) EBIT is earnings before interest and taxes and together with EBITDA, are an indicator of a company's profitability; 14) Net income is calculated as sales revenues minus cost of goods sold, selling, general and administrative expenses, operating expenses, depreciation, interest, taxes, and other expenses; 15) Total debt is calculated by adding up a company's debt liabilities, which are categorized as short and long-term debt; 16) Income tax expense is the amount of expense that a business recognizes in an accounting period for the government tax related to its taxable profit; 17) Cash from operations indicates the amount of money a company brings in from its ongoing, regular business activities, such as producing and selling goods or providing a service to customers; 18) Cash from investing activities reports how much cash has been generated or spent from various investment-related activities in a specific period. Investing activities include purchases of physical assets, investments in securities, or the sale of assets; 19) Cash flow from financing is a section of a company's cash flow statement, which shows the net flows of cash that are used to fund the company. Financing activities include transactions involving debt, equity, and dividends; 20) Free cash flow to firm is the cash a company produces through its operations, less the cost of investments in assets, depreciation, taxes, and working capital.

Analysis were performed using IBM SPSS Statistics 26 (Statistical Package for Social Sciences) 2 methods: 1) factor analysis: to precisely identify the relationships between the different 
companies' capital structure indicators in the Baltic States stock market listed companies; 2) hierarchical cluster analysis: to obtained an agglomeration of the different companies' capital structure indicators in the Baltic States stock market listed companies to be used in determining number of clusters with using elbow rule. 3) K-means cluster analysis was used to group Baltic States stock market companies in the predetermined by elbow rule number of clusters.

Factor Analysis is considered an interdependence method for dealing with metric data. In factor analyses we are looking for hidden factors that may explain common sources of variance between variables (Fabrigar \& Wegener, 2012). Hierarchical cluster analysis aim is categorizing, i.e., the creation of groups of objects to their similarities (Brandimarte, 2011, King, 2015) and it was done in 2 steps: first using hierarchical clustering method and based on the obtained agglomeration schedule and then applying elbow rule, obtained the number of clusters to be used as input for step two - K-means cluster analysis. The concept of K-means cluster is to create k number used defined number of clusters - which should group observations in clusters, where observations in one cluster are as similar as possible, while clusters must be as different from each other as possible.

Financial indicators were obtained from Bloomberg data base in 2019 and calculated of each sample listed company during research period in 2004-2018 (Bloomberg L.P., 2019).

\section{Results and Discussion}

\subsection{Baltic States Stock Market Listed Companies' Factor Analysis.}

In order to perform factor analysis, first it is necessary verify if the sample is suitable for factor analysis based the judgement on Kaiser-Meyer-Olkin (KMO) and Bartlett's test. Using 50 Baltic States stock market listed companies' 20 absolute value indicators, Authors' conclude, that KMO of sampling adequacy is 0.787 and according to C.A.Cerny \& H.F.Kaiser (1977) classification from 0.7-0.79 of obtained result is middling. Bartlett's test significance indicator (Sig. $=0.000$ ) is below 0.05 and indicates that factor analysis might be applied and useful. The 20 absolute value indicators of 50 Baltic States stock market listed companies', employed in the analysis, initially were grouped in 3 complex factors, which met the criterion that their eigen value had to be greater or equal to 1, which thus explained $91 \%$ of the total dispersion, which is a very high value for this indicator, since only $9 \%$ of variance is explained by other factors. The complex factors (after rotation with Varimax method), the indicators included in them, and their factor loads are presented in Table 1.

Table 1. Factor analysis results for the absolute value indicators of 50 Baltic States stock market listed companies in 2004-2018

\begin{tabular}{|l|c|l|c|}
\hline Indicator (explained information, \%) & $\begin{array}{l}\text { Factor } \\
\text { load }\end{array}$ & $\begin{array}{l}\text { Indicator (explained information, } \\
\%)\end{array}$ & $\begin{array}{c}\text { Factor } \\
\text { load }\end{array}$ \\
\cline { 1 - 2 } Factor 1. Overall business operations (43.3\%) & \multicolumn{2}{|l|}{ Factor 2. Debt factor (35.1\%) } \\
\cline { 1 - 2 } Income tax expense & 0.92 & Total debt & 0.96 \\
\hline Net income & 0.92 & Long-term borrowing & 0.93 \\
\hline Market capitalization & 0.86 & Net debt & 0.90 \\
\hline EBIT & 0.84 & Non-current liabilities & 0.85 \\
\hline Cash from operations & 0.83 & Total assets & 0.71 \\
\hline EBITDA & 0.81 & Short term borrowing & 0.64 \\
\hline Cash from investing activities & -0.77 & & \\
\hline
\end{tabular}


MANAGEMENT AND ECONOMICS

\begin{tabular}{|l|c|l|r|}
\hline Total equity & 0.74 & \multicolumn{2}{|l|}{} \\
\cline { 1 - 2 } Sales revenues & 0.71 & \multicolumn{2}{|l|}{ Factor 3. Financing cash flow (13.4\%) } \\
\hline Current liabilities & 0.70 & & \multicolumn{2}{|l|}{-0.97} \\
\hline Current assets & 0.69 & Cash flow from financing & 0.94 \\
\hline Cash on the balance sheet items & 0.58 & Free cash flow to firm & \\
\hline
\end{tabular}

Source: Authors' calculations.

Complex factor 1 - Overall business operations - explains $43.3 \%$ of the variance of the Baltic States stock market listed companies' capital structure and this factor groups the largest number of indicators -12 or $60 \%$ of their total number. Complex factor 1 combines indicators from all 3 financial statements - balance sheet, income statement and cash flow statement, in addition it includes both sides of balance sheet: assets and total equity and liabilities side. It also includes stock market indicator: market capitalization. The most essential factor load is specific to the variables such as income tax expense and net income (each 0.92), market capitalization (0.86), EBIT (0.84), cash from operations (0.83), EBITDA (0.81), that points to the companies' ability to finance everyday business. Cash from investing activities is -0.77 and indicates that companies are investing into their assets. Total equity, sales revenues, current liabilities, current assets, cash on the balance sheet items factor load varies from 0.74 to 0.58 . Complex factor 1 loadings can be explained similarly as regression coefficients, that income tax expense is closely correlated with the complex factor 1, so are most other items, which are strongly positively corelated with complex factor 1 , while cash flow from investing is strongly negatively correlated. This is logical since in cash flow statement negative cash flow from investing means, that a company is investing in purchasing assets or otherwise known as investing, the positive investing cash flow would mean selling or disposing its assets. Therefore, in the context of complex factor 1, if all factors increase, that improves financial and business of the company and its assets. One factor, which stands out in the overall is current liabilities within the context of the rest of the variable with highest loading in the complex factor 1 . While as indicated in the correlation output part, this indicator helps to explain the general business operations and its impact to the revenue generation and market value, as noted previously.

The factor analysis produced standardised values of each company for each complex factor, enabling to explain the results obtained - the size and direction of deviation from the average value of 0 . The differences, based on the values obtained, were classified into following value levels: 1) a large deviation - factor values smaller than -1 or greater than 1 ; 2) a normal deviation - factor values within a range from -1 to -0.5 and from 0.5 to $1 ; 3$ ) a small deviation - factor values within a range from -0.5 to 0.5 . The factor analysis reveals that in complex factor 1 there is close to equal split between companies being in the group from -1 to -0.5 and -0.5 to 0.5 . This shows that there are unifying factors and financial statement parameters, which are common among Baltic States stock market listed companies' financials. Complex factor 1 score regression results (Table 2) indicate that majority of companies 24 or $48 \%$ have small deviation, normal deviation have 22 companies or $44 \%$, but 4 companies for $8 \%$ has a large deviation from the mean.

Table 2. Detailed characteristics of Complex factor 1 - Overall business operations

\begin{tabular}{|l|c|l|}
\hline $\begin{array}{l}\text { Value } \\
\text { levels }\end{array}$ & $\begin{array}{l}\text { Number of } \\
\text { companies }\end{array}$ & Characteristics \\
\hline $\begin{array}{l}\text { From } \\
-1 \quad \text { to }\end{array}$ & 17 & $\begin{array}{l}\text { Based on overall business performance, companies have either negative net income, or } \\
\text { comparably low net income - with mean value in the group of negative } 0.29 \text { mill. }\end{array}$ \\
\hline
\end{tabular}




\section{MANAGEMENT AND ECONOMICS}

\begin{tabular}{|c|c|c|}
\hline-0.5 & & $\begin{array}{l}\text { EUR, as well as with small market cap c.a. } 7.6 \text { mill. EUR on average. Compared with } \\
\text { other groups, it is the lowest. Companies in this group are generating low EBIT ( } 0.10 \\
\text { mill. EUR on average) and cash from operations (mean value of } 0.47 \text { mill.EUR), when } \\
\text { compared to following three groups, as well as investing relatively small amounts in } \\
\text { the new assets. Mean sales revenues are also the lowest among groups, mean value } \\
13.17 \text { mill. EUR. Those companies' net investments are on the lower side, mean value } \\
-0.81 \text { mill. EUR, when compared to other groups' significantly higher investments. } \\
\text { Thus, this group companies can be categorized as small companies, with low income, } \\
\text { low investment and cash. }\end{array}$ \\
\hline $\begin{array}{l}\text { From } \\
-0.5 \\
\text { to } 0.5\end{array}$ & 24 & $\begin{array}{l}\text { This group has the typical profile of Baltic States stock market listed company and it is } \\
\text { following: these companies are larger in size, more profitable, with net income mean } \\
\text { value of } 4.6 \text { mill. EUR, when compared to previous group, though smaller than } \\
\text { compared to next group. These companies generate mean sales revenues of } 116 \text { mill. } \\
\text { EUR, their mean market capitalization is } 83 \text { mill. EUR, while cash from operation - } \\
11.4 \text { mill. EUR, EBITDA - } 15 \text { mill. EUR, EBIT - } 7.5 \text { mill. EUR and they invest more } \\
\text { when compared to previous group: mean value of }-10 \text { mill. EUR in investment cash } \\
\text { flow. }\end{array}$ \\
\hline $\begin{array}{l}\text { From } \\
0.5 \text { to } \\
1\end{array}$ & 5 & $\begin{array}{l}\text { There are even larger companies by market capitalization, mean value of } 151 \text { mill. } \\
\text { EUR when compared to previous two groups, they are on average more profitable } \\
\text { (almost twice when compared to previous group's mean net income), with current } \\
\text { assets more than } 105 \text { mill. EUR, that generates mean sales revenues of } 271 \text { mill. EUR, } \\
\text { cash from operation }-15.1 \text { mill. EUR, EBITDA }-23 \text { mill. EUR on average, EBIT - } \\
17 \text { mill. EUR, but they invest less than previous group companies, only mean value of } \\
-7.4 \text { mill. EUR in investing cash flow indicator. }\end{array}$ \\
\hline $\begin{array}{l}\text { More } \\
\text { than } 1\end{array}$ & 4 & $\begin{array}{l}\text { These are large and strong companies, with mean value of current assets } 136 \text { mill. } \\
\text { EUR. They generate mean sales revenues of } 388 \text { mill. EUR, and their mean market } \\
\text { capitalization is close to } 500 \text { mill. EUR. These are companies with large cash } \\
\text { generating capabilities, that is cash from operation - } 83.4 \text { mill. EUR, EBITDA more } \\
\text { than } 87 \text { mill. EUR on average, EBIT - } 46 \text { mill. EUR, their investment cash flow } \\
\text { indicates that they invest also more, mean cash flow from investing -71.4 mill. EUR. }\end{array}$ \\
\hline
\end{tabular}

Source: Authors' calculations.

Complex factor 2 - Debt factor - explains 35.1\% (Table 1) of the variance of the Baltic States stock market listed companies' capital structure absolute indicators responsible for debt part of the balance sheet and this complex factor groups the second largest number of indicators 6 or $30 \%$ of their total number. Complex factor 2 includes indicators almost all relates to debt component of balance sheet, such as: total debt, long-term borrowing, net debt, non-current liabilities, and short-term borrowing, with exception of total assets indicator - which is asset side of balance sheet indicator. The most significant load in complex factor 2 are carried by total debt (0.96), long term borrowing (0.93), net debt (0.90), and non-current liabilities (0.85), that is most of which is attributed to the debt part and long-term part of liabilities, thus long-term liabilities are more impacting complex factor 2 rather than short- term borrowing part, which are liabilities repayable within next 12 months. It indicates also, that overall borrowing is more impacting overall financials rather than the split between the long-term and short-term proportion of debt. Complex factor 2 score regression results (Table 3) indicate that majority of companies 44 or $88 \%$ have small deviation, normal deviation have 4 companies or $8 \%$, but 2 companies for $4 \%$ has a large deviation from the mean. 
Table 3. Detailed characteristics of Complex factor 2 - Debt factor indicators

\begin{tabular}{|c|c|c|}
\hline $\begin{array}{l}\text { Value } \\
\text { levels }\end{array}$ & $\begin{array}{l}\text { Number of } \\
\text { companies }\end{array}$ & Characteristics \\
\hline $\begin{array}{l}\text { From } \\
-1 \text { to } \\
-0.5\end{array}$ & 3 & $\begin{array}{l}\text { Here are grouped } 3 \text { companies, with lowest mean total debt value of } 16.80 \text { mill. EUR, } \\
\text { as well as long-term borrowing, this can be explained better, when evaluating net debt, } \\
\text { since net debt is negative for those group companies, on average }-24.11 \text { mill. EUR, it } \\
\text { shows that these companies hold large cash reserves and don't need debt, especially } \\
\text { this can be reinforced when looking at mean total asset value, which is } 361.39 \text { mill. } \\
\text { EUR. This group could be considered that their capital structure consists mainly of } \\
\text { equity and they are not dependent on external financing. }\end{array}$ \\
\hline $\begin{array}{l}\text { From } \\
-0.5 \\
\text { to } 0.5\end{array}$ & 44 & $\begin{array}{l}\text { This group creates average Baltic States stock market listed company profile for } \\
\text { complex factor } 2 \text {. Mean value of total debt is } 18.67 \text { mill. EUR, while it is slightly more } \\
\text { than for group } 1,16.8 \text { mill. EUR, but significantly less than for the next two groups. } \\
\text { Long-term borrowing mean value } 16.56 \text { mill. EUR and net debt of } 21.99 \text { mill. EUR, } \\
\text { this is interesting in the context of mean value of total debt, since net debt is higher } \\
\text { than total debt, implying the low cash balances of the companies grouped here. } \\
\text { Breakdown of non-current liabilities is significantly lower than in any other group, } \\
\text { with mean value of } 22.22 \text { mill. EUR. These companies have on average the lowest } \\
\text { total asset value, mean value of } 100.56 \text { mill. EUR, while in this group is also ESO1L } \\
\text { LH* with more impressive total asset value of } 1265.34 \text { mill. EUR. Short-term } \\
\text { borrowing mean value is slightly more than half of the total debt mean value, and is } \\
10.46 \text { mill. EUR. }\end{array}$ \\
\hline $\begin{array}{l}\text { From } \\
0.5 \text { to } \\
1\end{array}$ & 1 & $\begin{array}{l}\text { In this group is only one company - LNR1L LH*, which has significant assets of } \\
841.04 \text { mill. EUR, and low total debt of } 93.82 \text { mill. EUR compared to its assets, while } \\
\text { high debt when compared to previous } 2 \text { groups, and its short-term borrowing is less } \\
\text { than } 22 \% \text { of its total debt, and is } 20.60 \text { mill. EUR. }\end{array}$ \\
\hline $\begin{array}{l}\text { More } \\
\text { than } 1\end{array}$ & 2 & $\begin{array}{l}\text { This group is comprised of two companies, LGD1L LH* and TAL1L ET*, both are } \\
\text { very large companies, with highest among all other group total debt, with mean value } \\
\text { of } 406.52 \text { mill. EUR, and highest asset value, mean value } 1057.95 \text { mill. EUR. Most } \\
\text { proportion of their debt is long-term, as short-term debt component mean value of } \\
68.65 \text { mill. EUR is only } 17 \% \text { of total debt mean value. These companies are also most } \\
\text { leveraged, their total debt mean value calculated against mean total asset value is } 38 \% \text {, } \\
\text { while in previous three groups it is respectively } 5 \%, 19 \%, 11 \% \text {. }\end{array}$ \\
\hline
\end{tabular}

*Baltic States stock market listed company's ticker and exchange symbol.

Source: Authors' calculations.

Complex factor 3 - financing cash flow - explains 13.4\% (Table 1) of the variance of the Baltic States stock market listed companies' absolute value indicators and this factor groups has the smallest number of indicators -2 or $10 \%$ of their total number. Both indicators are related to cash flow -from financing and free cash flow to firm. Cash flow from financing is negatively correlated (-0.97), while free cash flow to firm is positively correlated (0.94), however, when in essence they represent similar outcome, since cash flow from financing is negative, when company is repaying its obligations more than taking on new liabilities. To estimate if that is the case, it is necessary to look at the distance from the centre of the factor are each company and their indicators in the complex factors standing, to be able to estimate the common patterns in the Baltic States stock market listed companies' financials. Complex factor 3 score regression results (Table 4) indicate that majority of companies 37 or $74 \%$ have small deviation, normal deviation have 8 companies or $16 \%$, but 5 companies for $10 \%$ has a large deviation from the mean.

Table 4. Detailed characteristics of Complex factor 3 - Factor of financing cash flow 


\begin{tabular}{|l|c|l|}
\hline $\begin{array}{l}\text { Value } \\
\text { levels }\end{array}$ & $\begin{array}{l}\text { Number of } \\
\text { companies }\end{array}$ & Characteristics \\
\hline $\begin{array}{l}\text { Less } \\
\text { than }\end{array}$ & 1 & $\begin{array}{l}\text { For complex factor 3, ESO1L LH is only company in this group, they have 42.93 mill. } \\
\text { EUR cash from financing activities, meaning that company is borrowing intensively or } \\
\text { constantly, and a negative free cash flow to the firm. This indicates that company can } \\
\text { no generate sufficient cash to cover its operations. }\end{array}$ \\
\hline $\begin{array}{l}\text { From } \\
-1 \text { to } \\
-0.5\end{array}$ & 5 & $\begin{array}{l}\text { In this group are companies, with also positive financing cash flow, meaning that they } \\
\text { are also borrowing more compared to the amounts paid out, while it is less than in the } \\
\text { first group, mean value of 7.34 mill. EUR, and also negative free cash flow to the firm: } \\
-13.65 \text { mill. EUR. }\end{array}$ \\
\hline $\begin{array}{l}\text { From } \\
-0.5 \\
\text { to 0.5 }\end{array}$ & 37 & $\begin{array}{l}\text { Majority of companies are group in this group, and is characterized as companies with } \\
\text { mean financing cash flow of -0.78 mill. EUR, meaning that these companies are } \\
\text { paying out either dividends to shareholders, or repaying loan to lenders more than } \\
\text { borrowing. Free cash flow to firm mean value is 1.24 mill. EUR. }\end{array}$ \\
\hline $\begin{array}{l}\text { From } \\
0.5 \text { to }\end{array}$ & 3 & $\begin{array}{l}\text { In this group are three companies, all Tallinn stock exchange listed, TKM1T ET, } \\
\text { TAL1T ET and MRK1T ET, with mean financing cash flow of -7.97 mill. EUR and } \\
\text { free cash flow to the firm mean value of 3.54 mill. EUR, however TAL1T ET free } \\
\text { cash flow to firm is negative, which signals that it has issues with sufficient cash } \\
\text { generation. }\end{array}$ \\
\hline $\begin{array}{l}\text { More } \\
\text { than 1 }\end{array}$ & 4 & $\begin{array}{l}\text { In this group are companies with the largest financing cash flow, mean value of -28.48 } \\
\text { mill. EUR and also largest free cash flow to the firm, mean value of 28.77 mill. EUR. } \\
\text { These are also one of the largest companies listed on the Baltic States stock market. }\end{array}$ \\
\hline
\end{tabular}

Source: Authors' calculations.

The performed analysis and all three complex factors reinstate the aim that funding and capital structure are important factors in both overall running business operations, as a separate component and as a source of actual cash flow.

\subsection{Baltic States Stock Market Listed Companies' Cluster Analyses.}

Cluster analysis were done in two steps. In Baltic States stock market listed companies' absolute value indicators analysis out of 50 companies they according to elbow rule were grouped in 4 clusters. It appears that based selected financial statement indicators for 45 stock market listed companies are grouped in same cluster number 4. This allows to conclude that indeed majority of Baltic States stock market listed companies have absolute value indicator similarities. ANOVA analysis ( $\mathrm{Sig}=0.000)$ re-confirms that all variables should be introduced to the cluster analysis. There are 5 outliers, since 1 or 3 companies are not enough to form a cluster themselves, they are thus outliers. These companies are:

1) Cluster 1 - ESO1L LH, is characteristic as one of the largest companies on the Baltic States stock market, with average market capitalization of almost 707 mill. EUR, total assets 1265 mill. EUR, sales revenues 622 mill. EUR, EBITDA 130 mill. EUR and modest debt, compared to the assets of 98 mill. EUR., and is investing in its assets, with investing cash flow of 176 mill. EUR, while positive financing cash flow of 43 mill. EUR, indicating the need for external financing inflow, which is reconfirmed by negative free cash flow to the firm of 69 mill. EUR;

2) Cluster 2 - TEL1L LH, LNR1L LH, GZE1R LR, these are other significantly large companies, with market capitalization of 375-545 mill. EUR, with insignificant debt proportion in the capital structure 7-94 mill. EUR, large cash balances 33-49 mill. EUR, significant sales and EBITDA, respectively 265-418 mill. EUR, and 61-97 mill. EUR. and 
repaying or paying out more from financing cash flow than receiving and significant free cash flow to the firm 26-46 mill. EUR;

3) Cluster 3 - TAL1T ET, another one of the largest Baltic States stock market listed companies, with 554 mill. EUR market capitalization, 1536 mill. EUR total assets, 754 mill. EUR total debt, 687 mill. EUR net debt, 769 mill. EUR in revenues and 135 mill. EUR in EBITDA, and investing cash flow of -93 mill. EUR, while financing cash flow of 9 mill. EUR and negative free cash flow to the firm: -6 mill. EUR;

4) Cluster 4 - 45 companies, incl. 13 from Estonia, 16 from Latvia, 16 from Lithuania (BAL1R LR, DPK1R LR, GRZ1R LR, GRD1R LR, HMX1R LR, KA11R LR, LJM1R LR, OLF1R LR, RAR1R LR, RER1R LR, RJR1R LR, RKB1R LR, RRR1R LR, SAF1R LR, VEF1R LR, VSS1R LR, ARC1T ET, BLT1T ET, EEG1T ET, HAE1T ET, MRK1T ET, NCN1T ET, PKG1T ET, PRF1T ET, SFG1T ET, SKN1T ET, TKM1T ET, TPD1T ET, TVEAT ET, APG1L LH, AUG1L LH, GRG1L LH, KNF1L LH, KNR1L LH, LGD1L LH, LNA1L LH, LNS1L LH, PTR1L LH, PZV1L LH, RSU1L LH, SNG1L LH, UTR1L LH, VBL1L LH, VLP1L LH, ZMP1L LH) - see Table 5.

Table 5. Baltic States Stock market listed companies' absolute value indicator description in the cluster 4

\begin{tabular}{|l|l|c|c|c|c|c|}
\hline No. & Cluster 4 indicators & Mean & Min & Max & STDEV.S. & STDEV.S./Mean \\
\hline 1. & Market capitalization & 51.78 & 0.54 & 310.61 & 66.49 & 1.28 \\
\hline 2. & Current assets & 33.57 & 0.30 & 197.29 & 40.41 & 1.20 \\
\hline 3. & Cash on the balance sheet items & 4.99 & 0.02 & 32.83 & 7.48 & 1.50 \\
\hline 4. & Total assets & 84.31 & 1.60 & 579.62 & 102.96 & 1.22 \\
\hline 5. & Total equity & 46.43 & 1.53 & 351.95 & 61.22 & 1.32 \\
\hline 6. & Non-current liabilities & 15.82 & 0.00 & 139.71 & 25.82 & 1.63 \\
\hline 7. & Long-term borrowing & 12.39 & 0.00 & 85.27 & 18.88 & 1.52 \\
\hline 8. & Current liabilities & 22.20 & 0.06 & 113.52 & 25.62 & 1.15 \\
\hline 9. & Short term borrowing & 8.37 & 0.00 & 69.75 & 12.02 & 1.44 \\
\hline 10. & Net debt & 15.16 & -12.69 & 83.10 & 21.95 & 1.45 \\
\hline 11. & Sales revenues & 79.94 & 0.64 & 518.56 & 105.62 & 1.32 \\
\hline 12. & EBITDA & 7.75 & -2.97 & 32.02 & 8.55 & 1.10 \\
\hline 13. & EBIT & 4.32 & -3.27 & 22.60 & 5.74 & 1.33 \\
\hline 14. & Net income & 2.95 & -12.38 & 17.63 & 5.30 & 1.80 \\
\hline 15. & Total debt & 17.42 & 0.00 & 87.18 & 20.00 & 1.15 \\
\hline 16. & Income tax expense & 0.55 & -2.17 & 4.33 & 1.03 & 1.87 \\
\hline 17. & Cash from operations & 5.52 & -4.26 & 30.98 & 7.58 & 1.37 \\
\hline 18. & Cash from investing activities & -4.53 & -22.87 & 0.53 & 5.42 & -1.20 \\
\hline 19. & Cash flow from financing & -0.55 & -17.70 & 16.07 & 4.88 & -8.87 \\
\hline 20. & Free cash flow to firm & 0.17 & -34.25 & 13.99 & 6.83 & 40.18 \\
\hline Source & & & & \\
\hline
\end{tabular}

Source: Authors' calculation.

Table 5 presented information on the average portrait of the Baltic States stock market listed company. The size wise - mean value of market capitalization of 52 mill. EUR, with total assets exceeding market capitalization value and mean value of 84 mill.EUR. Mean sales revenues exceeding mean market capitalization and is 80 mill. EUR, while only 8 mill. EUR in mean EBITDA value. That implies that companies are struggling to generate significant amount of EBITDA despite significantly large sales revenues, as well as it is not completely converging to their market capitalization. Total debt mean value is 17 mill. EUR, in this indicator there is one of the smallest deviations, also calculated as standard deviation as a fraction of the mean. Among all indicators, the lowest standard deviation calculated against mean, is for EBITDA, total debt and current liabilities. 
Evaluating from the capital structure perspective, the companies mean debt value of 17 mill.EUR is $21 \%$ of total asssets' mean value. Short-term borrowing proportion in total debt is around half, that is $50 \%$, thus can be assumed that the loan maturity is broken down almost equally between short-term and long-term portion. Since short-term is up to 12 months, then average duration of the loan can be around 2 years. Largest deviations of standard deviation from the mean are for the following absolute value indicators: cash flow from financing and free cash flow to firm, this indicates that in these two absolute value indicators companies are the most different in their financial standings.

Autors agreed with J.Pera (2019) ,that the stock exchanges of CEE countries may be excellent places for capital investments for small and medium investors accepting a higher level of risk. ...Enhancing investor involvement, including foreign investors, affects the increase in the liquidity of stocks on the market". This could ensure total economic growth in the region.

\section{Conclusion}

Stock market is an important topic in finance and it is needed for development of companies and, thus economy. Baltic States stock market 50 listed companies' 20 absolute value indicators comprehensive analysis aloud to conclude that this market is relatively homogeneous, but has a small number of very large companies with significantly different performance indicators. Using factor and cluster analysis can be concluded: 1) All companies' indicators were grouped in 3 complex factors, which thus explained $91 \%$ of the total dispersion, which is a very high value for this indicator, since only $9 \%$ of variance is explained by other factors; 2) Complex factor 1 - Overall business operations - explains $43.3 \%$ of the variance of the Baltic States stock market listed companies' capital structure and this factor groups the largest number of indicators - 12 or $60 \%$ of their total number; 3 ) Complex factor 2 - Debt factor - explains $35.1 \%$ of the variance of the Baltic States stock market listed companies' capital structure absolute indicators responsible for debt part of the balance sheet and this complex factor groups the second largest number of indicators -6 or $30 \%$ of their total number; 4) Complex factor 3 - financing cash flow - explains $13.4 \%$ of the variance of the Baltic States stock market listed companies' absolute value indicators and this factor groups has the smallest number of indicators -2 or $10 \%$ of their total number; 5)The cluster analysis provides information on the average portrait of the Baltic States stock market listed company is clustered on one cluster - $90 \%$ of Baltic States stock market listed companies. Thus, establishing the portrait of an average company of: market capitalization mean value of 52 mill. EUR, with total assets exceeding it, with mean value of 84 mill. EUR. Mean sales revenues exceeding mean market capitalization and is 80 mill. EUR, while only 8 mill. EUR in mean EBITDA value. The results of this analysis could be used for policy making to stimulate Baltic States stock market development in the future.

\section{Acknowledgment}

The research was supported by the National Research Programme "Latvian Heritage and Future Challenges for the Sustainability of the State" project "Challenges for the Latvian State and Society and the Solutions in International Context (INTERFRAME-LV)". The publication was funded by grant "Strengthening Research capacity in the Latvia University of Life Sciences and Technologies" project No Z39. 


\section{References}

[1] Bloomberg L.P. 2019. Data base, Bloomberg Terminal. Accessed 21.10.2019.

[2] Bóta, G., Ormos, M. (2015). Development of stock market pricing in Central and Eastern Europe through two decades after the transition. Empirica, Volume 42, pp. 685-708. https://ezproxy.1lu.lv:2071/10.1007/s10663-014-9272-0.

[3] Brandimarte, P. (2011). Quantitative Methods: An Introduction for Business Management. Hoboken, N.J.: $\quad$ Wiley, $912 \quad$ p. $\quad$ Available: $\quad$ https://www.wiley.com/enlv/Quantitative+Methods\%3A+An+Introduction+for+Business+Management-p-9781118023488.

Accessed July 23, 2020.

[4] Bustos, O., Pomares-Quimbaya, A. (2020). Stock market movement forecast: A Systematic review. Expert Systems with Applications. Volume 156, Issue 15, 15 p. https://doi.org/10.1016/j.eswa.2020.113464.

[5] Cerny, C.A., Kaiser, H.F. (1977). A Study of a Measure of Sampling Adequacy for Factor-Analytic Correlation Matrices. Multivariate Behavioral Research, Volume 12, Issue 1, pp. 4347, DOI: 10.1207/s15327906mbr1201_3.

[6] Chen, H., Zheng, X., Zeng, D.D. (2020). Analyzing the co-movement and its spatial-temporal patterns in Chinese stock market. Physica A: Statistical Mechanics and its Applications, Volume 555, $14 \mathrm{p}$. https://doi.org/10.1016/j.physa.2020.124655.

[7] Chovancova, B., Hudcovsky, J. (2016). Quantitative Easing in Europe and its Impact on the Stock Market. Montenegrin Journal of Economics, Volume 12, No. 3, pp. 155-165. DOI: 10.14254/1800$5845.2016 / 12-3 / 11$.

[8] Fungáčová Z., Godlewski Ch.J., Weill L. (2020). Does the type of debt matter? Stock market perception in Europe. The Quarterly Review of Economics and Finance, Volume 75, February 2020, pp. 247-256. https://doi.org/10.1016/j.qref.2019.04.009.

[9] Jach A. (2017). International stock market comovement in time and scale outlined with a thick pen. Journal of Empirical Finance, Volume 43, September 2017, pp. 115-129. https://doi.org/10.1016/j.jempfin.2017.06.004.

[10] Johnson, R., Soenen, L. (2002). Asian economic integration and stock market comovement. Journal of Financial Research, Volume 25, pp.141-157. https://doi.org/10.1111/1475-6803.00009.

[11] Kaužēns E. (2018). Kapitāla tirgus Latvijā - trešajā desmitgadē, bet joprojām vājšs. Vai ir alternatīvas? Available: https://www.makroekonomika.lv/kapitala-tirgus-latvija-tresaja-desmitgade-bet-joprojam-vajsvai-ir-alternativas

[12] King, R.S. (2015). Cluster Analysis and Data Mining: An Introduction. Dulles, Virginia: Mercury Learning \& Information; $316 \mathrm{p}$.

[13] Fabrigar, L.R., Wegener, D.T. (2012). Exploratory Factor Analysis. Oxford: Oxford University Press; $159 \mathrm{p}$.

[14] Liu, Z., Zhang, T., Li, W., Kuang, X. (2018). The neighborhood effects of provincial-level stock market participation in China. Physica A: Statistical Mechanics and its Applications, Volume 509, pp.459-468. DOI: $10.1016 / j$.ribaf.2020.101203.

[15] Marshall A., McCann L., McColgan P. (2019). The market reaction to debt announcements: UK evidence surrounding the global financial crisis. The British Accounting Review, Volume 51, Issue 1, January 2019, pp. 92-109. https://doi.org/10.1016/j.bar.2018.04.001. 
[16] Nitoi, M., Pochea, M.M. (2016). Testing financial markets convergence in Central and Eastern Europe: A non-linear single factor model. Economic Systems, Volume 40, Issue 2, June 2016, pp. 323-334. https://doi.org/10.1016/j.ecosys.2016.02.002.

[17] Nyasha, S., Odhiambo, N.M. (2014). Bank-Based Financial Development and Economic Growth. A Review of International Literature. Journal of Financial Economic Policy, 6, issue 2, p. 112-132. https://doi.org/10.1108/JFEP-07-2013-0031.

[18] Pera, J. (2019). The Effectiveness of Investing in Stock Exchange Markets in Central and Eastern European Countries with Regard to NYSE2-LSE-HKSE2. A Comparative Risk Analysis. Comparative Economic Research. Central and Eastern Europe, Volume 22, Number 2, 20 p. http://doi.org/10.2478/cer-2019-0016.

[19] Podgorny, B. (2017). The Russian stock market as a social space: a theoretical basis. Economic AnnalsXXI, Volume 164(3-4), pp. 20-23. https://doi.org/10.21003/ea.V164-04.

[20] Pradhan, R.P., Arvin, M.B., Mahendhiran, N., Bennett S.E. (2019). Inter-linkages between competition and stabilisation policies in the banking sector and stock market development in Europe. Applied Economics, Volume 51, Issue 39, pp.4313-4324. DOI: 10.1080/00036846.2019.1591603.

[21] Thomas, A., Spataro, L. (2018). Financial Literacy, Human Capital and Stock Market Participation in Europe. Journal of Family and Economic Issues, Volume 39, pp.532-550. Available: https://ezproxy.1lu.lv:2071/10.1007/s10834-018-9576-5.

[22] World Economic Forum (2019). Annual Report 2018-2019, 130 p. Available: http://www3.weforum.org/docs/WEF_Annual_Report_18-19.pdf Accessed July 25, 2020.

[23] World Economic Forum (2020). The Global Risks Report 2020. Insight Report 15th Edition In partnership with Marsh \& McLennan and Zurich Insurance Group, 102 p. Available: http://www3.weforum.org/docs/WEF_Global_Risk_Report_2020.pdf.

[24] Xiaoye, J. (2018). Downside and upside risk spillovers from China to Asian stock markets: A CoVaRcopula approach. Finance Research Letters, Volume 25, June 2018, pp.202-212. https://doi.org/10.1016/j.frl.2017.10.027.

[25] Yin, L., Wei, Y., Han, L. (2020). Firms' profit instability and the cross-section of stock returns: Evidence from China. Research in International Business and Finance, Volume 53, 19 p. https://doi.org/10.1016/j.ribaf.2020.101203.

[26] Zakharkin, O., Zakharkina, L., Antoniuk, N. (2017). A comparative analysis of stock market volatility depending on investment time horizon. Economic Annals-XXI, Volume 167(9-10), pp. 49-52. https://doi.org/10.21003/ea.V167-10.

[27] Zhang, X., Zheng, X., Zeng, D.D. (2017). The dynamic interdependence of international financial markets: An empirical study on twenty-seven stock markets. Physica A: Statistical Mechanics and its Applications, Volume 472, pp.32-42. DOI: 10.1016/j.physa.2016.12.062. 